\title{
An Introduction to the Japanese Groundwater Animals with Reference to their Ecology and Hygienic Significance
}

\author{
by \\ Kôichi MATSUMOTO*

\section{AN INTRODUCTION TO THE JAPANESE GROUNDWATER ANIMALS}

In the first half of this century, little was known of the groundwater animals of Japan. In 1916, Prof. Ijima and Dr. Kaburaki gave a description of a hypogean planarian as the first groundwater animal of Japan. Following this description, eleven species were recorded from wells and caves during the thirty-five years up to 1950 . Thus, only twelve species of animals were registered as groundwater animals of Japan in the first four decades of this century.

Since 1950, a number of groundwater animals have been collected and described from caves and wells of Japan, and the present list of the troglobites from the groundwaters of Japan comprises almost two hundred species which are classified in eight phyla, thirteen classes, eighteen orders, forty-seven families, and at least seventy-seven genera.

However, numerous specimens of Oligochaeta, Ostracoda, Cyclopoida, and particularly those of microorganisms such as Protozoa, Hydra, Nematoda, and Rotatoria, etc. still remain undescribed. Because sufficient numbers of mature specimens in satisfactory condition are not available for study, some material of Nemertinea, Archiannelida, Turbellaria, Dytiscidae, Phreatodytidae, etc. are also left undescribed.

In recent years, a remarkable decrease in the number of wells available for the collection of material has forced some speleobiologists to divert their activities to the field of the interstitial fauna of rivers and seashores.

Besides the troglobites listed in Table 1, various groups of troglophiles and trogloxenes have been obtained from the groundwaters of Japan. Some of them are significant as a biological indicator of well-water pollution upon which I shall comment later on.

Among the aquatic troglobites of Japan, one of the noteworthy groups may

\footnotetext{
* Tokyo Metropolitan Hygienic Research Institute, 3-24-1 Hyakunin-cho, Shinjuku-ku, Tokyo, Japan 160 .
} 
Table 1. Troglobites reported from undergroundwaters of Japan

CILIATA

ANTHOZOA

TURBELLARIA

ENOPLA

GASTROPODA

ARCHIANNELIDA

OLIGOCHAETA

HIRUDINEA

ECHIUROIDEA

ARACHNIDA

\author{
PROTOZOA \\ Suctoria: \\ Hypotrichida:
}

COELENTERATA

Actiniaria:

\section{PLATYHELMINTHES}

Tricladida

Planariidae:

Kenkiidae:

NEMERTINEA

Hoplonemertinea:

MOLLUSCA

Caenogastropoda

Hydrobiidae:

\section{ANNELIDA}

Nerillidae:

Neoligochaeta

Haplotaxidae:

Lumbriculidae:

Gnathobdellida

Erpobdellidae:

\section{ARTHROPODA}

Acarina

Hydrovolziidae:

Protziidae:

Torrenticolidae:

Limnesiidae:

Hygrobatidae:

Unionicolidae:

Feltriidae:

Axonopsidae:

Aturidae:

Momoniidae:

Mideopsidae:

*Uchidastygacaridae:

* Nipponacaridae:

*Kantacaridae:

Hungarohydracaridae:

Arrenuridae:

Halacaridae:
Tokophrya phreaticum

l sp. (undescribed)

1 n.g., n.sp. (undescribed)

Phagocata papillifera, Ph. albata, Ph. tenella Speophila sp. (undescribed)

Sphalloplana sp. (undescribed)

2 spp. (undescribed)

*Akiyoshia (s.str.) 2 spp.

*Akiyoshia (Saganoa) $6 \mathrm{spp}$.

2 spp. (undescribed)

Nerilla sp. (undescribed)

Haplotaxis gordioides, H. gastrochaetus Hrabea ogumai

Erpobdella sp. (undescribed)

I sp. (undescribed)

* Stygovolzia uenoi

Wandesia japonica

Torrenticola 2 spp.

* Kawamuracarus elongatus

Atractides 4 spp.

Neumania 3 spp.

Feltria 3 spp.

Lethaxona 4 spp., Axonopsis 9 spp., Ljania 5 spp.

* Uenaxonopsis nazensis

Frontipodopsis reticulatifrons var. okinawa

Aturus subterraneus

Stygomomonia 3 spp.

Mideopsis 13 spp.

*Uchidastygacarus 4 spp.

* Nipponacarus matsumotoi, N. miurai, N. japonicus

* Kantacarus matsumotoi

Bharatohydracarus 1 sp.

Arrenurus sp.

* Himejacarus morimotoi

Parasoldanellonyx typhlops japonicus

Soldanellonyx 4 spp. 


\section{CRUSTACEA}

INSECTA

\section{PISCES}

Ostracoda

Podocopa:

Copepoda

Cyclopoida

Cyclopidae:

\section{Harpacticoida \\ Ectinosomidae: \\ Phyllognathopodidae: \\ Laophontidae: \\ Ameridae:}

Canthocamptidae:

Parastenocaridae:

\section{Malacostraca}

Bathynellacea

Bathynellidae:

Parabathyhellidae:

\section{Amphipoda \\ Ingolfiellidae: \\ Pontogeneiidae:}

Gammaridae:

Isopoda

Asellidae:

Parasellidae:

Microcerberidae:

Coleoptera

*Phreatodytidae:

Dytiscidae:

\section{VERTEBRATA}

Percida

Gobiidae:
Podocopa spp. (undescribed)

\section{Eucyclops miurai}

Megacyclops viridis takefuensis

Acanthocyclops morimotoi

Diacyclops disjunctus

D. languidoides japonicus,

D. languidoides suoensis

Speocyclops yezoensis

Ectinosoma japonica

Phyllognathopus viguieri

Onychocamptus mohamed

Nitocra 3 spp.

Nitocrella 4 spp.

Ceuthonectes mirabilis

Attheyella 3 spp.

Bryocamptus 4 spp.

Paracamptus nakamurai

Epactophanes richardi

Elaphoidella $5 \mathrm{spp}$.

Parastenocaris $4 \mathrm{spp}$.

Bathynella 12 spp., 1 subsp.

Eobathynella 1 sp., 2 subspp.

Allobathynella 5 spp., 1 subsp.

* Nipponbathynella miurai

Ingolfiella spp. (undescribed)

Paramoera relictica, P. tsushimana

* Awacaris kawasawai

Pseudocrangonyx 5 spp.

* Eocrangonyx japonicus

* Neoniphargus (Eoniphargus) kojimai

Eriopisa sp. (undescribed)

Bogidiella sp. (undescribed)

Asellus (s.str.) 7 spp.

*Asellus (Phreatoasellus) 5 spp.

*Uenasellus iyoensis

* Nipponasellus 5 spp.

Mackinia 3 spp.

Microcerberus kiiensis, M. fukudai, M. boninensis

* Phreatodytes relictus

Phreatodytes $2 \mathrm{n}$. spp. (undescribed)

* Morimotoa phreatica

Morimotoa 2 n. spp., 1 n. subsp. (undescribed)

Luciogobius pallidus

L. albus

* Families, genera and subgenera endemic to Japan. 
be the marine derivatives, such as Actiniaria, Nemertinea, Archiannelida, Echiurida, and Parasellidae, etc. An Actiniaria has been obtained from a slightly saline pool (salinity: $14.89 \%$ ) in a lava cave on Isl. Fukue-jima near

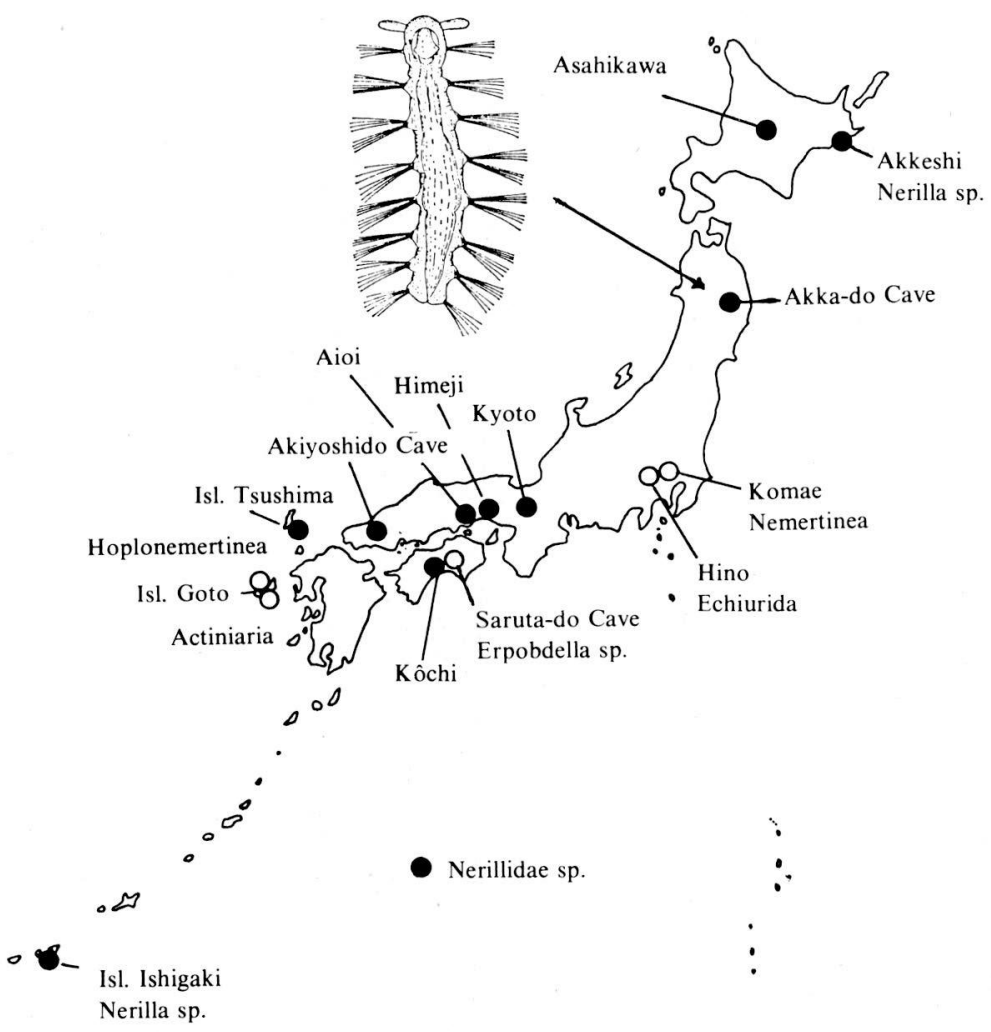

Fig. 1: Distribution of troglobiontic Actiniaria, Nemertinea, Hirudinea, Nerillidae. and Echiurida.

Nagasaki together with a cave fish, and it is supposed to belong to a new species and new genus. A specimen of Hoplonemertinea has been collected from another lava cave on the same island and one more Nemertinea has been obtained from a driven well in the suburb of Tokyo. Archiannelida have been found from wells and caves in Hokkaido, Honshu, Shikoku, Kyushu, and Isl. Tsushima and comprise, at least, two species of Nerillidae. According to Dr. S. Ueno's note, they are rather related to Thalassochaetus, a marine genus from Kiel Bay, than to Troglochaetus. Living material of Echiurida from a well near Tokyo unfortunately disintegrated during microscopical observation. Thus, these groups are not yet sufficiently investigated with the exception 
of Parasellidae, because of difficulties in fixation of materials and microscopical observation of living ones. As to the Parasellid genus, three species of Mackinia have been described from Japan, South Korea, and Far Eastern Siberia
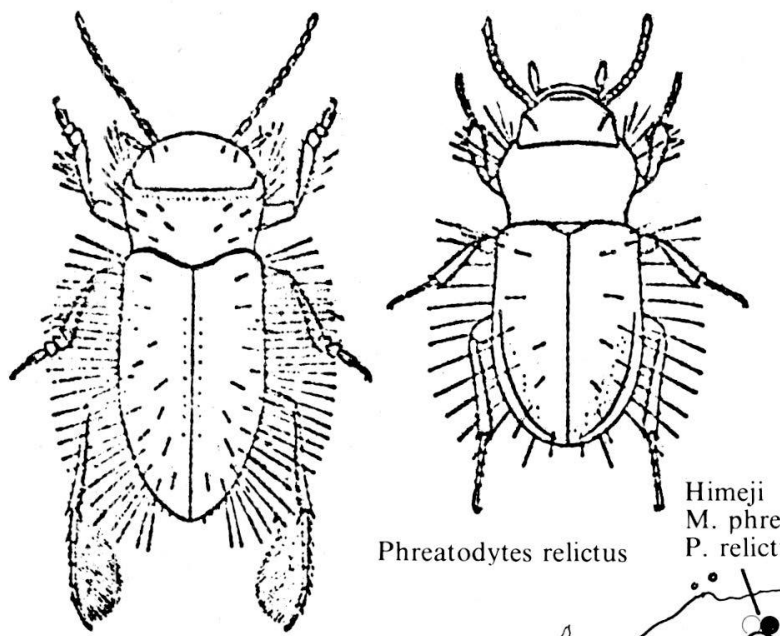

Phreatodytes relictus

Morimotoa phreatica

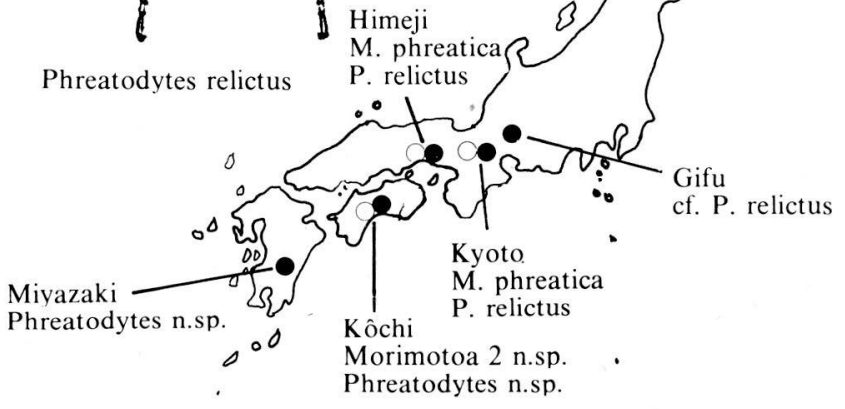

$0 \approx$

$00^{\circ}$

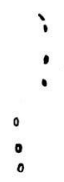

Fig. 2: Distribution of Dytiscidae and Phreatodytidae

near Nahotoka. The other noteworthy groups are the archaic relicts such as Bathynellacea, Phreatodytes and Morimotoa, etc. The former order is widely distributed throughout Japan and comprises more than nineteen species which are classified in four genera of two families. The latter two genera of aquatic beetles distributed in western Japan are both anophthalmic and depigmented and comprise at least six species. As to the last group, interstitial ancient relicts such as Ingolfiella and Microcerberus have been recently found in the groundwaters of Japan. Further, the occurrence of the two genera of Kenkiidae, Speophila and Sphalloplana, though not yet sufficiently investigated, is zoogeo- 
graphically interesting, because they are the relatives of the North American cavernicoles.

Most of the species of the Japanese aquatic troglobites are endemic to Ja-

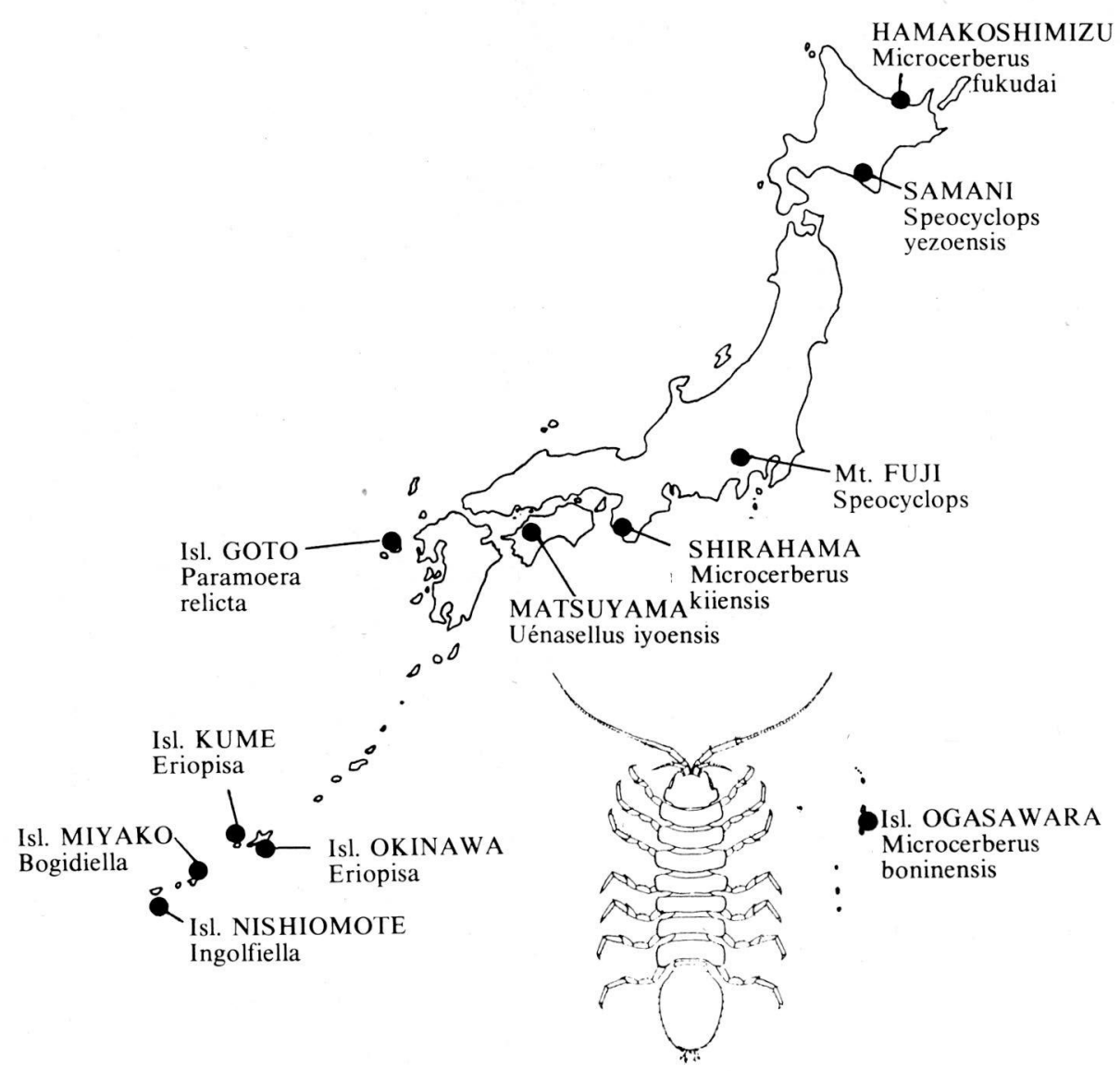

Fig. 3: Distribution of noteworthy troglobiontic Crustacea

pan, and what is more some of their genera and families are also peculiar to Japan. According to Prof. Imamura, three of the seventeen families of the troglobiontic Hydrachnellae: Uchidastygacaridae, Nipponacaridae and Kantacaridae, are endemic to Japan. Further, the troglobiontic Coleopteran family, Phreatodytidae is a peculiar family of Japan. As to the endemic genera, sixteen genera of various animals can be listed: Luciogobius, Morimotoa, Phreatodytes, Nipponasellus, Uenasellus, Eocrangonyx, Awacaris, Nipponbathynella, 
Himejacarus, Kantacarus, Nipponacarus, Uchidastygacarus, Uenaxonopsis, Kawamuracarus, Stygovolzia, and Akiyoshia.

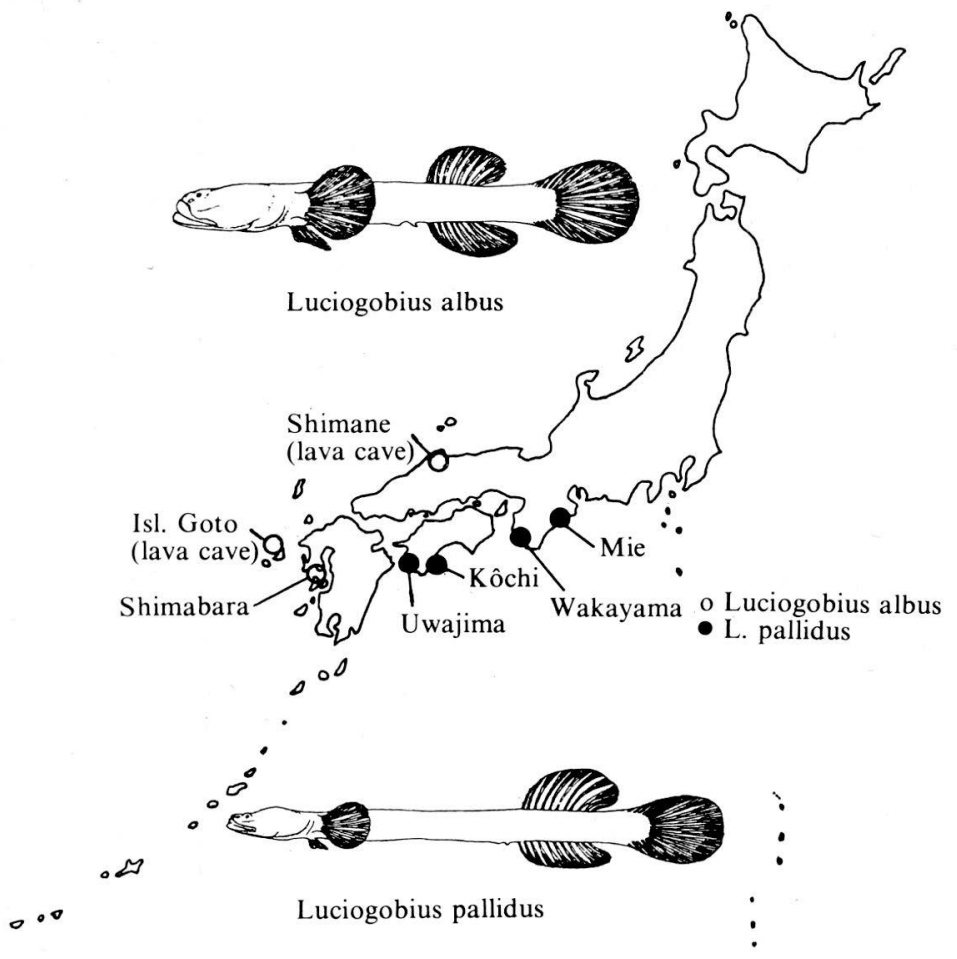

Fig. 4: Distribution of troglobiontic Gobiidae

\section{SOME ACCOUNTS ON THE ECOLOGY OF THE JAPANESE GROUNDWATER ANIMALS}

As to the ecology of the groundwater animals of Japan, sufficient material for discussion is not available. Therefore, the writer would like to introduce brief notes on their habitats obtained during the collection of materials and the examination of well-waters. A great majority of the aquatic troglobites of Japan have been obtained from wells and some of them occur also in caves, but only a few have been collected from springs, river-beds, and the bottom of deep lakes. Recently, however, a number of specimens have been collected from interstitial media of rivers and lakes as well as seashores. The general features 
of the wells from which the groundwater animals were obtained are summarised as follows:

1) Construction of wells: In Japan, groundwater animals have never been obtained from bored wells deeper than 30 meters. Most of them have been collected from driven wells with a depth of less than 10 meters. Planktonic and nektonic troglobites, such as Cyclopoida, Mackinia, and Gammaridae, etc. occur both from driven and dug wells. However, benthic troglobites, such as Gastropoda, Oligochaeta, and Planariidae, etc. are rarely obtain ed from the pumps of dug wells. Asellus kawamurai seems to prefer open dug wells. Generally speaking, groundwater animals available for investigation were rarely obtained from wells with a motor pump.

2) Situation of wells: Groundwater fauna of wells near rivers is much more variable than that of wells further away and from the former various kinds of exogenous animals such as leeches and larvae of aquatic insects, etc. are also obtained occasionally.

3) Bottom materials of wells: Groundwater animals are rare in wells with a rocky bed or sediments of volcanic ashes. Most inhabit wells which have clean sandy sediments mixed with small amounts of organic detritus in alluvial regions. Generally, Hydrachnellae, Ostracoda, Bathynellacea, and Nipponasellus, etc. are the representatives of these types. However, Cyclopoida, Oligochaeta, Asellus and Mackinia, etc. seem to prefer wells with muddy bottoms containing much organic sediment. It is noteworthy that Asellus kawamurai seems to prefer open dug wells which have decaying leaves on the bottom. Large types of aquatic Oligochaeta are frequently obtained together with large amounts of their excreta.

4) Water temperature of wells: Water temperature of fifteen riverside wells with depths of 4-5 meters in Hachioji City in Tokyo Pref., where more than thirty species of various groundwater animals were collected, ranged from $21^{\circ} \mathrm{C}$ to $25^{\circ} \mathrm{C}$ in August and fell to $9-13^{\circ} \mathrm{C}$ in January. Most aquatic cavernicoles are known to be cold stenotherms, but the groundwater animals in the Hachioji area were found to be considerably tolerant to thermal fluctuations.

5) Color, turbidity, and odor of well-waters: Mos $\hat{\imath}$ of the groundwater animals preferably inhabit clear, colorless, and odoriess water, however, Mackinia, Cyclopoida, Amphipoda, and Oligochaeta, etc. have been obtained rarely also from opaquely turbid waters. Further, A. kawamurai has been collected in great numbers from unused open dug wells, the water of which has a conspicuous odor of hydrogen sulfide. In many cases, well-waters in which large Oligochaeta live have a fishy smell.

6) $\mathrm{pH}$ of well-waters: $\mathrm{pH}$ values of all of 521 wells where the groundwater animals were obtained were less than 7.8 and most of them, 455 wells, ranged from 5.7 to 7.0 rather than $7.0-7.8$.

7) Chemical properties of well-waters: As to the chemical properties of well-waters in which the groundwater animals occurred, all the results of the examination of chlorine ion, total hardness, $\mathrm{KMnO}_{4}$ consumption, and total residues were within the limits of drinking water criteria except for those of nitrogen compounds and iron. On the whole, more than $20 \%$ of the wells, from 
which Paludicola, Oligochaeta, Cyclopoida, Asellus, Nipponasellus, Gammaridae, and even Bathynellacea were obtained, were found to be polluted to the extent of being unfit for drinking.

8) Dissolved oxygen in well-waters: Amounts of dissolved oxygen in thirteen wells in Hachioji City situated on the riverside area ranged from 1.75 ppm. to $10.75 \mathrm{ppm}$ in January, 1960.

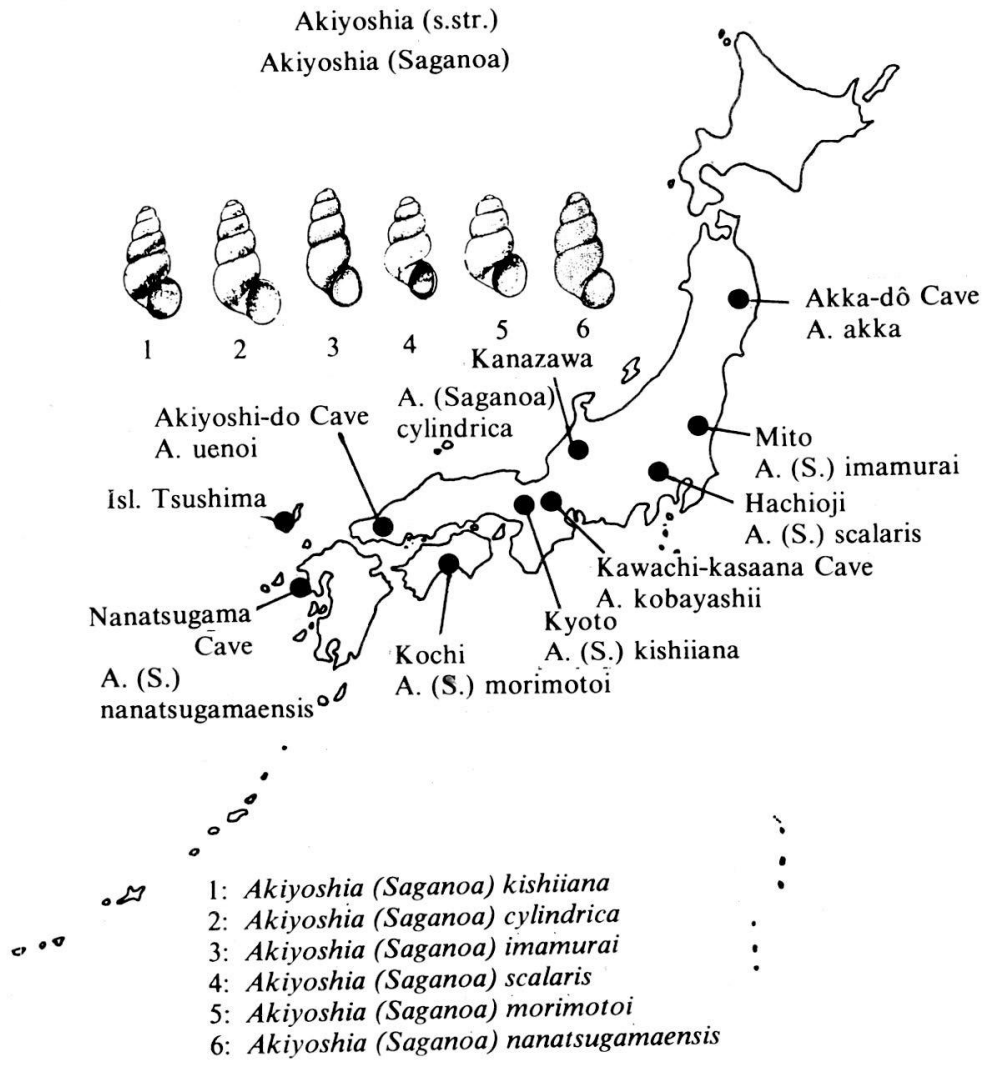

Fig. 5: Distribution of Akiyoshia (Gastropoda, Hydrobiidae)

9) Bacteriological quality of well-waters: Because the bacteriological examination of common drinking waters is much more sensitive for organic water pollution than the chemical examination, groundwater animals were obtained regardless of the bacteriological water quality. As to the results of the Coliaerogenes group test, most of the groundwater animals were obtained from wells bacteriologically unfit for drinking. Concerning the bacterial counts, 
Table 2. Nitrogen Compounds in Well-water and Undergroundwater Animals.

\begin{tabular}{|c|c|c|c|c|c|c|c|c|c|c|c|c|c|}
\hline \multirow{3}{*}{$\begin{array}{l}\text { N-Compounds } \\
\text { Animals } \\
\end{array}$} & \multicolumn{12}{|c|}{ Numbers of Wells } & \multirow{3}{*}{ Tota } \\
\hline & \multicolumn{4}{|c|}{$\mathbf{N H}_{3}-\mathbf{N}$} & \multicolumn{4}{|c|}{$\mathbf{N O}_{3}-\mathbf{N}$} & \multicolumn{4}{|c|}{$\mathrm{NO}_{2}-\mathbf{N}$} & \\
\hline & - & \pm & + & ++ & - & \pm & + & ++ & - & \pm & + & ++ & \\
\hline Paludicola & 10 & 1 & 3 & & 1 & 5 & 7 & 1 & 9 & 3 & 1 & 1 & 14 \\
\hline Oligochaeta & 36 & 3 & 10 & 2 & 16 & 13 & 19 & 3 & 36 & 9 & 4 & 2 & $\overline{51}$ \\
\hline Cyclopoida & 65 & 10 & 6 & 2 & 15 & 27 & 35 & 6 & 60 & 13 & 6 & 4 & 83 \\
\hline Harpacticoida & 7 & & & & & 5 & 2 & & 5 & 2 & & & 7 \\
\hline Ostracoda & 26 & 1 & 2 & & 11 & 11 & 6 & 1 & 23 & 4 & 1 & 1 & 29 \\
\hline Mackinia & 68 & 8 & 6 & 2 & 24 & 29 & 26 & 5 & 63 & 7 & 7 & 2 & 84 \\
\hline $\begin{array}{r}\text { Asellus (s.str.) } \\
\text { hilgendorfii } \\
\end{array}$ & 4 & & 1 & & 2 & 1 & 1 & 1 & 4 & & & 1 & 5 \\
\hline $\begin{array}{l}\text { Asellus (s.str.) } \\
\text { musashiensis }\end{array}$ & 18 & 5 & 1 & 1 & 6 & 7 & 11 & 1 & 19 & 5 & 1 & & 25 \\
\hline $\begin{array}{r}\text { Asellus (Phr.) } \\
\text { kawamurai } \\
\end{array}$ & 2 & 3 & & & 1 & 1 & 3 & & 3 & & 2 & & 5 \\
\hline $\begin{array}{l}\text { Nipponasellus } \\
\text { hubrichti }\end{array}$ & 43 & 4 & 4 & & 19 & 19 & 11 & 2 & 40 & 4 & 5 & 2 & 51 \\
\hline Gammaridae & 70 & 13 & 7 & 4 & 29 & 28 & 31 & 6 & 68 & 12 & 11 & 3 & 94 \\
\hline Bathynellacea & 22 & 5 & & 1 & 10 & 5 & 10 & 3 & 19 & 3 & 4 & 2 & 28 \\
\hline Hydracarina & 11 & & 1 & & 9 & 2 & & 1 & 11 & & & 1 & 12 \\
\hline $\begin{array}{l}\text { Hydrobiidae } \\
\text { (Akiyoshia) }\end{array}$ & 10 & & & & 6 & 4 & & & 10 & & & 1 & 10 \\
\hline Dytiscid & 1 & 1 & & & & 1 & 1 & & & 2 & & & 2 \\
\hline $\begin{array}{l}\text { Total Number of } \\
\text { Wells examined }\end{array}$ & 393 & 54 & 41 & 12 & 149 & 158 & 163 & 30 & 375 & 64 & 42 & 19 & 500 \\
\hline
\end{tabular}


Table 3. Hygienic Grouping of Animals Reported from Well-waters of Japan

\begin{tabular}{|c|c|c|c|}
\hline \multirow{2}{*}{ Groups } & \multicolumn{2}{|c|}{ Aquatic animals } & \multirow[b]{2}{*}{$\begin{array}{l}\text { Terrestrial animals } \\
\text { (exogenous) }\end{array}$} \\
\hline & Troglobites & $\begin{array}{l}\text { Troglophiles and } \\
\text { Trogloxenes }\end{array}$ & \\
\hline Group 1 & $\begin{array}{l}\text { Tokophrya phreaticum } \\
\text { Hypotrichida sp. } \\
\text { Phagocata } 3 \text { spp. } \\
\text { Speophila } \mathrm{sp} . \\
\text { Sphalloplana sp. } \\
\text { Nemertinea sp. } \\
\text { Akiyoshia } 6 \text { spp. } \\
\text { Nerillidae } 2 \text { spp. } \\
\text { Haplotaxis } 2 \text { spp. } \\
\text { Hrabea ogumai } \\
\text { Echiuroidea sp. } \\
\text { Hydrachnella } 70 \text { spp. } \\
\text { Ostracoda spp. } \\
\text { Cyclopoida } 7 \text { spp. } \\
\text { Harpacticoida } 24 \text { spp. } \\
\text { Bathynellacea } 19 \text { spp. } \\
\text { Asellidae } 17 \text { spp. } \\
\text { Uenasellus iyoensis } \\
\text { Mackinia } 3 \text { spp. } \\
\text { Gammaridae } 10 \mathrm{spp} . \\
\text { Phreatodytes relictus } \\
\text { Phreatodytes } 2 \text { spp. } \\
\text { Morimotoa phreatica } \\
\text { Morimotoa } 2 \text { spp. } \\
\text { Luciogobius } 2 \text { spp. }\end{array}$ & \multirow[t]{2}{*}{$\begin{array}{l}\text { Hydra sp. } \\
\text { Craspedacusta iseana } \\
\text { Dugesia japonica } \\
\text { Phagocata } 2 \text { spp. } \\
\text { Dendrocoelopsis } \\
\quad \text { lacteus } \\
\text { Nematoda spp. } \\
\text { Keratella cochlearis } \\
\text { Euchlanis sp. } \\
\text { Lepadella ovalis } \\
\text { Asplanchna sp. } \\
\text { Callidina sp. } \\
\text { Rotaria rotatoria } \\
\text { Chaetonotus sp. } \\
\text { Nais sp. } \\
\text { Aeorosoma hemprichi } \\
\text { Stylaria lacustris } \\
\text { Pristima } \text { sp. } \\
\text { Hypsibius augusti } \\
\text { Ostracoda spp. } \\
\text { Cyclopoida } 11 \text { spp. } \\
\text { Harpacticoida } 4 \text { spp. } \\
\text { Asellus hilgendorfii } \\
\text { Rivulogam. nipponensis } \\
\text { Paramoera ezonis } \\
\text { Chironomidae sp. } \\
\text { Culicidae sp. }\end{array}$} & \multirow[t]{4}{*}{$\begin{array}{l}\text { Bipalium fuscatum } \\
\text { B. trilineatum } \\
\text { Plumonata spp. } \\
\text { Eisenia foetida } \\
\text { Lumbricidae spp. } \\
\text { Araneida spp. } \\
\text { Acarina spp. } \\
\text { Oniscoidea spp. } \\
\text { Taltridae spp. } \\
\text { Diplopoda spp. } \\
\text { Chilopoda spp. } \\
\text { Collembola } 10 \text { spp. } \\
\text { Orthoptera spp. } \\
\text { Dermaptera spp. } \\
\text { Coleoptera spp. } \\
\text { Hymenoptera spp. } \\
\text { Diptera spp. } \\
\text { Anura sp. } \\
\text { Sauria sp. } \\
\text { Insectivora sp. } \\
\quad \text { (hair) } \\
\text { Rodentia sp. } \\
\quad \text { (hair) }\end{array}$} \\
\hline Group 2 & $\begin{array}{l}\text { Cyclopoida spp. } \\
\text { Asellus miurai } \\
\text { Asellus musashiensis } \\
\text { Nipponasellus hubrichti } \\
\text { Mackinia spp. } \\
\text { Pseudocrangonyx spp. }\end{array}$ & & \\
\hline Group 3 & Asellus kawamurai & $\begin{array}{l}\text { Mastigophora } 6 \text { spp. } \\
\text { Sarcodina } 14 \text { spp. } \\
\text { Ciliata } 9 \text { spp. } \\
\text { Rotaria rotatoria }\end{array}$ & \\
\hline $\begin{array}{l}\text { Group } 4 \\
\text { (exogenous) }\end{array}$ & & $\begin{array}{l}\text { Branchiura sowerbyi } \\
\text { Tubificidae spp. } \\
\text { Hirudinea } 3 \mathrm{spp} . \\
\text { Daphnia pulex } \\
\text { Perlidae sp. } \\
\text { Trichoptera sp. } \\
\text { Psychoda } \mathrm{sp} . \\
\text { Elmidae sp. } \\
\text { Neonectes natrix } \\
\text { Zaitzevia } \mathrm{sp} . \\
\text { Luciola sp. }\end{array}$ & \\
\hline
\end{tabular}


Paludicola, Oligochaeta, Cyclopoida, Mackinia, Asellus, and Pseudocrango$n y x$, etc. were found to occur also in highly contaminated waters containing more than 5,000 bacteria per $1 \mathrm{ml}$ of water. According to Japanese drinking water criteria, bacterial counts per $1 \mathrm{ml}$ of water is limited to be less than 100 and the Coli-aerogenes group must be negative in $50 \mathrm{ml}$ of water. On the whole, greater numbers of groundwater animals were found to occur in clean well-waters at least within the limits of chemical drinking water criteria, however, from the point of bacteriological safety standards, most of the wells from which groundwater animals were obtained are regarded to be unfit for drinking.

10) Population of groundwater animals: In most cases, the population of the groundwater animals obtained from wells was extremely small. However, the writer has obtained more than three hundred individuals of Mackinia from 350 liters of well-water, about one hundred fifty individuals of Asellus musashiensis from 300 liters of water, about one hundred individuals of $A$. miurai from 500 liters of water, and about fifty individuals of $A$. kawamurai from 200 liters of water. These large populations of groundwater animals were observed only in polluted wells.

\section{HYGIENIC CONSIDERATION ON THE GROUNDWATER ANIMALS OF JAPAN}

As the writer has mentioned, to date, more than 190 species of troglobites and about fifty species of troglophiles have been collected from well-waters of Japan. However, none of them are known to be directly detrimental to human health. In this sense groundwater animals may seem to have little bearing to human health problems. However, a number of trogloxenes and various terrestrial animals have also been found in well-waters and some of them appear to be significant indicators of well-water pollution. Therefore, exact knowledge of their taxonomy and ecology may be necessary to those concerned with the purity of drinking water. All kinds of macroorganisms which occurred in wellwaters in Japan have been provisionally classified into four groups and arranged in Table 3. Most of the troglobites listed in Group l were collected from well-waters which were clean, at least within the limit of chemical drinking water criteria, and in most cases their populations were extremely small. Therefore, as their occurrence is rare, they themselves are apt to be overlooked. However, smallness of their population size per se does not assure the safety of drinking water quality; this is particularly so as to bacteriological pollution. Further, some of them listed in Group 2 were occasionally observed to multiply to a great number when the well-water was polluted. This phenomenon has been observed in Asellus, Mackinia, Pseudocrangonyx, and Cyclopoida. Their multiplication in well-waters may apparently indicate the pollution of water. A minority of troglobites and a majority of troglophilous or trogloxenous microorganisms are listed as Group 3. They were found to prefer naturally eutrophic environments of well-waters with much organic sediment. Asellus kawamurai is the representative of this group. Most of the troglophiles and trogloxenes which directly invaded wells from neighbouring surface waters 
such as rivers, ponds, and ditches, etc. are listed in Group 4. Their occurrence may suggest the presence of permeable passways through which they could reach the well and indicate a heavily contaminated condition of well-waters. Some of the Tubificidae, Hirudinea and aquatic insects are listed as members of this group.

Furthermore, most of the terrestrial animals shown in the table are commonly distributed in country districts and suburban areas. They live around or inside dug wells and occasionally fall into the water. Therefore, remains or parts of their bodies are occasionally pumped out from wells. Of course, their accidental presence in the well-water has no relation to the water quality. However, they themselves will be an undesirable origin of contamination, and they may imply an unhealthy state and an incomplete construction of wells. Earthworms, snails, slugs and Bipalium, etc. occur in wells situated in low and wet environments. Terrestrial arthropods are often found in crowded circumstances and sometimes invade wells during cold seasons seeking warmer wintering refuges. Furthermore, some species of Collembola, such as Onychiurus folsoni, are frequently found to swarm on the surface of well-waters.

Thus, a little ecological and taxonomical knowledge of the animals found in well-waters makes it at times possible to detect well-water pollution and to point to its origin.

Microorganisms, such as Algae, Protozoa, and Aschelminthes, etc., may be the most significant and sensitive indicator organisms for water pollution. Unfortunately, knowledge of these is extremely limited in Japan. Only the following is certain. The chlorophilous organisms are originally exogenous to groundwater environments and their presence is indicative of well-water pollution. This fact was carefully investigated by T. Koriyama (1952), who demonstrated that most of the well-waters which contained Chlorophyceae and chlorophilous Protozoa were not bacteriologically fit for drinking.

\section{SUMMARY}

1) Nearly two hundred species of troglobites are known from the groundwaters of Japan. Most of these troglobiontic species, sixteen of seventy-seven genera, and what is more, four of fortyseven families are endemic to Japan. Uchidastygacaridae, Nipponacaridae, and Kantacaridae are endemic acaridan families of Japan. The coleopterous family, Phreatodytidae, is also endemic to Japan.

2) Though studies on Protozoa, Turbellaria, Annelida, Aschelminthes, and Ostracoda, etc. remain sparse, the interstitial fauna is actively investigated recently and many specimens of Bathyneliacea, Ingolfiella, Bogidiella, Microcerberus, Pseudovermis (Opisthobranchia), and Nerillidae, etc. have been collected from freshwater and marine environments.

3) None of the troglobites is known to be directly detrimental to human health and most of them have been collected from well-waters which are regarded as chemically clean in many cases, but they have also been obtained occasionally from bacteriologically contaminated well-waters.

4) Ecological and taxonomic knowledge, of even the limited amount which we possess at present, has enabled us to utilize various animals which occur in well-waters as biological indicators of well-water pollution and to have some insight as to the origin of the pollution. 


\section{ZUSAMMENFASSUNG}

Beinahe zweihundert Arten Grundwassertiere sind aus den japanischen unterirdischen Gewässern bekannt. Die meisten von ihnen sind in Japan endemisch; an Gattungen sind sechzehn und an Familien sind vier, d.h. Nipponacaridae, Kantacaridae, Uchidastygacaridae, und Phreatodytidae, heimisch. Während Protozoa, Turbellaria, Annelida, Aschelminthes, Ostracoda, usw. wenig erforscht sind, werden in letzter Zeit die interstitiellen Grundwassertiere aktiv untersucht. Keines der genannten Grundwassertiere ist, soweit bisher bekannt, für die Menschen direkt gesundheitschädlich. Das Brunnenwasser, aus dem die meisten von ihnen entnommen worden sind, ist zwar in chemikalischer Hinsicht als klar anzusehen. Aber es kommt manchmal auch vor, daß sie im bakteriologisch verseuchten Brunnenwasser ermittelt werden. Verschiedene Tiere, die im Brunnenwasser gefunden werden, können als biologische Anzeiger für die Verseuchung des Brunnenwassers gebraucht werden und verhelfen uns zu weiterer Einsicht in die Ursprünge der Verschmutzung.

\section{ACKNOWLEDGEMENTS}

The writer would like to express his hearty gratitude to Dr. S. Husmann who has kindly given him the opportunity to read the present paper in the "Ist International Symposium on Groundwater Ecology" and to Prof. T. Gledhill who has corrected the manuscript. His hearty thanks also to Prof. T. Imamura, Dr. S. Ueno, Mr. Y. Morimoto, and Mr. Y. Miura who have kindly allowed him to use their valuable data in preparing the manuscript of the present paper. Further, he must owe much to Dr. G. Ohi who has given him friendly help in writing the original manuscript of the present paper. 


\section{REFERENCES}

Hamatani, I. and Nunomura, N. (1973). A new species of the interstitial Eolidacean genus Pseudovermis (Opisthobranchia) from Kii, Middle Japan. Publ. Seto Mar. Biol. Lab., XXI (2): 67-71.

Ito, T. (1974). A new species of marine interstitial isopod of the genus Microcerberus from Hokkaido. J. Fac. Sci. Hokkaido Univ. Ser. VI, Zool. 19 (2): 338-348.

(1975). A new species of marine interstitial isopod of the genus Microcerberus from the Bonin Islands. Annot. Zool. Japon. 48 (2): 119-128.

Koriyama, T. (1952). On a biological survey of well-waters in Sendai City. Rep. Miyagi Pref. Hyg. Lab. 17. (in Japanese).

Matsumoto, K. (1956). The organisms found in wells, and their significance as the indicators for polluted waters. (First Report). Annual Rept. Tokyo-to Lab. Med. Sci. 6: 81-108. (in Japanese).

- (1969). An introduction to phreatobiology. (1). Jour. Water and Waste. 11 (3): 237-245. (in Japanese).

(1969). An introduction to phreatobiology. (2). op. cit. 11 (4): 344-348. (in Japanese). (1969). An introduction to phreatobiology. (3). op. cit. 11 (6): 492-502. (in Japanese). (1969). An introduction to phreatobiology. (5). op. cit. 11 (8): 666-676. (in Japanese). (1969). An introduction to phreatobiology. (8). op. cit. 11 (12): 1027-1037. (in Japanese). (1970). An introduction to phreatobiology. (9). op. cit. 12 (2): 135-140. (in Japanese). (1970). An introduction to phreatobiology. (10). op. cit. 12 (4): 294-306. (in Japanese). (1970). An introduction to phreatobiology. (11). op. cit. 12 (5): 391-401. (in Japanese). (1970). An introduction to phreatobiology. (12). op. cit. 12 (6): 479-485. (in Japanese). (1970). An introduction to phreatobiology. (14). op. cit. 12 (10): 931-938. (in Japanese). (1970). An introduction to phreatobiology. (15). op. cit. 12 (11): 1023-1029. (in Japanese). (1971). An introduction to phreatobiology. (16). op. cit. 13 (4): 491-500. (in Japanese).

Nunomura, N. (1973). Description of Microcerberus kiiensis, n. sp.: Primary record of the suborder Microcerberidea (Crustacea, Isopoda) in Japan. Publ. Seto Mar. Biol. Lab., XXI (2): 87-93.

New illustrated encyclopedia of the fauna of Japan. Edited by Y. Okada, S. Uchida, and T. Uchida. (I). (1965). Hokuryu-kan, Tokyo. 679 pp. (in Japanese).

op. cit. (II). (1967). Hokuryu-kan, Tokyo. 803 pp. (in Japanese).

Tamiji Kawamura's "Freshwater Biology of Japan". Edited by M. Ueno (1973). Hokuryu-kan, Tokyo. 760 pp. (in Japanese).

Ueno, S. (1957). Blind aquatic beetles of Japan, with some accounts of the fauna of Japanese subterranean waters. Arch. f. Hydrobiol., 53 (2): 250-296.

(1970). The fauna of the insular lava caves in West Japan. I. General account. Bull. Nat. Sci. Mus. Tokyo, 13: 443-454. 